\title{
The characterization of DNA methylation-mediated regulation of bovine placental lactogen and bovine prolactin-related protein-I
}

\section{genes}

\author{
Yuki Nakaya ${ }^{1,4}$, Keiichiro Kizaki ${ }^{1}$, Toru Takahashi ${ }^{2}$, Osman V Patel ${ }^{3}$ and \\ Kazuiyoshi Hashizume*1
}

\begin{abstract}
Address: ${ }^{1}$ Laboratory of Veterinary Physiology, Department of Veterinary Medicine, Faculty of Agriculture, Iwate University, 3-18-8 Ueda, Morioka, Iwate 020-8550, Japan, ${ }^{2}$ National Institute of Agrobiological Sciences, Ikenodai 2, Tsukuba, Ibaraki 305-8602, Japan, ${ }^{3}$ Department of Biology, Grand Valley State University, College of Liberal Arts and Sciences, 212 Henry Hall 1 Campus Dr. Allendale, MI 49401, USA and ${ }^{4}$ Laboratory of Viral Pathogenesis, Center for Emerging Virus Research, Institute for Virus Research, Kyoto University, 53 Shogoin-Kawaharacho, Sakyo-ku, Kyoto 606-8507, Japan
\end{abstract}

Email: Yuki Nakaya - nakayayuki@gmail.com; Keiichiro Kizaki - kizaki@iwate-u.ac.jp; Toru Takahashi - tatoru@affrc.go.jp; Osman V Patel - patelo@gvsu.edu; Kazuiyoshi Hashizume* - kazuha@iwate-u.ac.jp

* Corresponding author

Published: 5 March 2009

BMC Molecular Biology 2009, 10:19 doi:10.1186/1471-2199-10-19
Received: 27 June 2008

Accepted: 5 March 2009

This article is available from: http://www.biomedcentral.com/1471-2199/10/19

(C) 2009 Nakaya et al; licensee BioMed Central Ltd.

This is an Open Access article distributed under the terms of the Creative Commons Attribution License (http://creativecommons.org/licenses/by/2.0), which permits unrestricted use, distribution, and reproduction in any medium, provided the original work is properly cited.

\begin{abstract}
Background: Bovine trophoblast binucleate cells (BNC) express a plethora of molecules including bovine placental lactogen (bPL, gene name is $b C S H I$ ) and bovine prolactin-related protein-I (bPRPI). BCSHI and bPRPI are members of the growth hormone $(\mathrm{GH}) /$ prolactin (PRL) gene family, which are expressed simultaneously in BNC and are central to placentation and the progression of pregnancy in cattle. However, there is a paucity of information on the transcriptional regulatory mechanisms of both the $b C S H I$ and bPRPI genes. Recent studies, however, have demonstrated that the expression of a number of genes is controlled by the methylation status of their promoter region. In the present study, we examined the cell-type-specific epigenetic alterations of the 5 '-flanking region of the $b C S H I$ and $b P R P I$ genes to gain an insight into their regulatory mechanisms.

Results: Analysis of 5-aza-2'-deoxycytidine treatment demonstrated that bCSHI expression is moderately induced in fibroblast cultures but enhanced in BT-I cells. Sodium bisulfite based sequencing revealed that $b C S H I$ is hypomethylated in the cotyledonary tissue but not in the fetal skin, and this pattern was not altered with the progression of pregnancy. On the other hand, the methylation status of $B P R P I$ was similar between the cotyledon and fetal skin. The bPRPI gene was exclusively hypermethylated in a bovine trophoblast cell-derived BT-I cell-line. While the activity of $b C S H I$ was similar in both BT-I and bovine fibroblast cells, that of $b P R P I$ was specific to BT-I. Treatment with a demethylating agent and luciferase assays provided in vitro evidence of the positive regulation of $b C S H I$ but not $b P R P I$.

Conclusion: This is the first report to identify the differential regulatory mechanisms of the $b C S H I$ and bPRPI genes and indicates that $b C S H I$ might potentially be the only transcript that is subject to DNA methyltransferase regulation. The data indicates the possibility of novel kinetics of induction of the synchronously expressed BNC-specific bCSHI and bPRPI transcripts, which may aid the understanding of the intricate regulation and specific role(s) of these important molecules in bovine placentogenesis and the progression of pregnancy.
\end{abstract}




\section{Background}

Bovine placental lactogen (bPL, gene name: $b C S H 1)$ and bovine prolactin-related protein 1 (bPRP1) are members of the growth hormone (GH)/prolactin (PRL) family $[1,2]$. The homology between $b C S H 1$ and $b P R P 1$ is $62 \%$ for nucleotides and $36 \%$ for amino acids [1]. Bovine PL is classified as a classical member of the GH/PRL gene family [3]. In contrast, thirteen isoforms of bPRP have been identified and are categorized as nonclassical members of this family [4-7]. BCSH1 has been detected in various mammalian species including humans $[1,8-13]$, while orthologues of PRP1 have been detected in several animals (e.g., rodent, cattle, goats, and sheep) [2,4-7,14-16]. In the ruminant placenta, $b C S H 1$ and $b P R P 1$ are concurrently detected in trophoblastic binucleate cells (BNC) $[17,18]$. The expression of both transcripts becomes apparent in BNC from about day 20 of gestation. Coincidentally, the earliest detection of the transcripts parallels the appearance of BNC in the fetal trophoblast, and studies indicate that $b C S H 1$ is a reliable marker of BNC morphogenesis $[17,18]$. However, the temporal profile of these two genes are disparate during gestation such that the expression level of $b \mathrm{CSH} 1$ increases with the progression of pregnancy; whereas, the $B P R P 1$ expression pattern is biphasic with a gradual increase up to mid-gestation followed by a period of steady decline $[19,20]$. Despite advances in the unraveling of GH/PRL gene sequences, structural characteristics, expression sites, and cell localization, little is known about their molecular regulatory mechanisms in bovines. Recent studies have revealed the transcriptional regulatory factors of the PL-family in other species; for example, Sp1 has been identified as an important factor for the expression of human PL; mouse PL-I has been shown to be activated by activator protein (AP) -1, GATA2, and GATA3; rat PL-II is reported to have binding sites for Ets and AP-1; and ovine PL is documented to be activated by AP-2 and GATA [21-25]. However, there is limited information on the factors that regulate the expression of the PRP gene, particularly in the artiodactyl species $[15,16]$. Recently, we reported that the AP-2 family may be involved in the regulation of these genes in bovine species [26], although additional studies are necessary to confirm this finding. However, a growing body of evidence suggests that mechanisms involving epigenetic changes regulate the expression of some genes [27-34]. Epigenetic modification involving DNA methylation has been demonstrated to be central to tissue-dependent gene expression, embryogenesis, and carcinogenesis [27-34]. We hypothesized that the differential expression patterns of $b C S H 1$ and $b P R P 1$ are controlled by DNA methylation, and in this study we investigated whether DNA methylation regulates the expression of the $b \mathrm{CSH} 1$ and bPRP1genes in trophoblast cells.

\section{Results \\ The effects of 5-aza-dC on bCSHI and bPRP I expression in cultured cells}

The $b$ CSH1 expression was moderately induced in 5-aza$\mathrm{dC}$-supplemented fibroblast cultures $(\mathrm{P}<0.05)$; whereas, there was an increase in the overall expression intensity in BT-1 5-aza-dC treated cultures $(\mathrm{P}<0.05)$ (Figure 1A and 1B). In contrast to bCSH1, bPRP1 expression was decreased in BT-1 cells, but no bPRP1 expression was detected in fibroblasts (Figure 1C and 1D).

\section{Determination of CPG sites in the 5'-flanking region of bCSHI and bPRPI}

The CpG sites in the 5'-flanking region of bCSH1 and bPRP1 were examined using Day 150 COT. In all, 19 CpG sites were detected in $b \mathrm{CSH} 1$, from -4090 to the transcription starting site, as is shown in Figure 2A. BPRP1 had 9 $\mathrm{CpG}$ sites from -860 to the transcription starting site, as is shown in Figure 3A.

The DNA methylation statuses of cotyledon and fetal skin Using samples from Day 150 COT and fetal skin (SKIN), the DNA methylation status of the 5'-flanking region of the $b C S H 1$ and $b P R P 1$ genes was examined using bisulfate sequencing.

\section{bCSHI}

We divided the 5 '-flanking region of $b C S H 1$ into 6 regions (region 1: -354 to $-147 \mathrm{bp}$; region 2: -992 to $-541 \mathrm{bp}$; region 3: -2099 to $-1651 \mathrm{bp}$; region $4:-2711$ to $-2300 \mathrm{bp}$; region 5: -3428 to -3103 bp; region 6 : -4094 to $-3742 \mathrm{bp}$ ) depending on the distribution of the CpG sites. DNA was hypomethylated in the COT but not in the SKIN samples. In all, 14 CpG sites (among -3343 to -215 bp) showed a significantly low methylation status $(\mathrm{P}<0.05)$. Seven of these $14 \mathrm{CpG}$ sites were assumed to be located between regions 1 and 2 (Figure 2B).

\section{bPRPI}

We divided the 5 '-flanking region of $b P R P 1$ into 2 regions (region 1: -495 to -75 bp; region 2: -963 to $-535 \mathrm{bp}$ ). The DNA methylation status was similar between the COT and SKIN samples. Only 3 CpG sites (-470, -269 and -197 $\mathrm{bp})$ in region 1 had a significantly low-level of methylation $(\mathrm{P}<0.05)$ (Figure 3B).

\section{Dynamic changes in the bCSHI and bPRPI gene methylation levels in cotyledonary tissue during gestation bCSHI}

We selected $7 \mathrm{CpG}$ sites in regions 1 and 2 to compare their methylation status during gestation (Figure 4A) based on our findings of the CpG sites that exhibited significantly low methylation levels in the day 150 COT samples, as shown in Figure 2. 
(A)

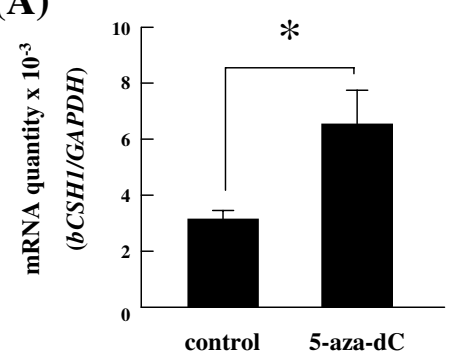

(C)

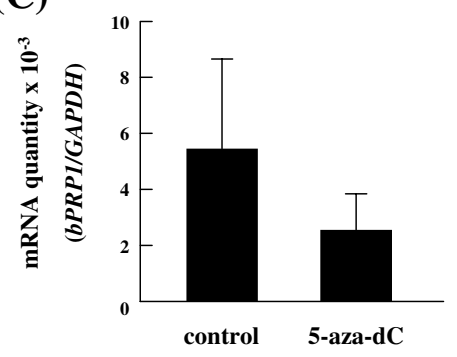

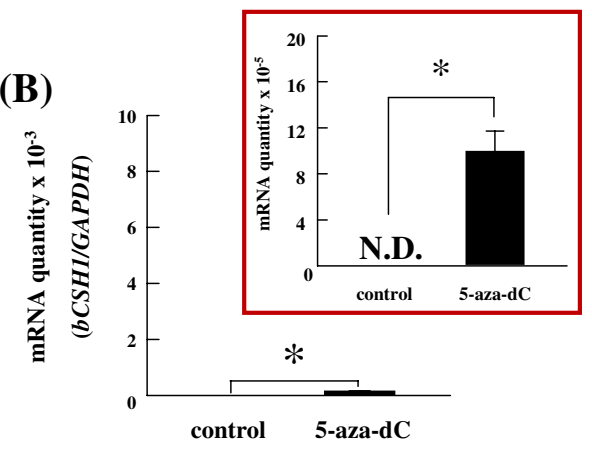

(D)

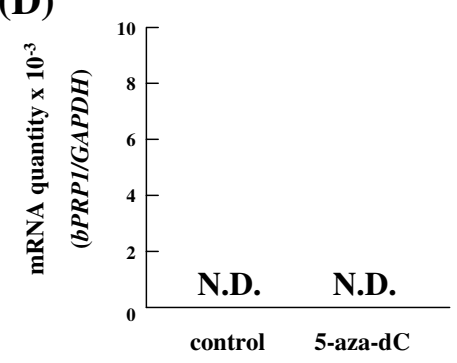

\section{Figure I}

The effects of 5-aza-dC on BT-I and endometrial fibroblast cells. The expression levels of $b C S H I(A, B)$ and $b P R P I$ (C, D) mRNA were determined by quantitative real-time RT-PCR. Ten $\mu M$ of 5 -aza-dC were added to both cell populations (A, C: BT-I; B, D: endometrial fibroblast cells). The expression levels were normalized to that of GAPDH mRNA. All results are displayed on a y-scale of $10^{-3}$, except for the insert in (B) where it is reduced to $10^{-5}$ to depict the low expression levels. Values are shown as the mean \pm SEM, and values marked with an asterisk are significantly different $(* P<0.05)$.

On day 90 of gestation, the methylation ratios at two CpG sites $(-580$ and -280$)$ were lower $(33.3 \%)$ in comparison to the other sites (53.3\% to $73.3 \%$ ). These lower ratios were maintained at the above loci throughout gestation. However, no results were significantly different $(P>0.05)$.

\section{bPRPI}

We examined a total of $9 \mathrm{CpG}$ sites in regions 1 and 2 during gestation (Figure 4B). On day 60 of gestation, 7 out of the 9 sites showed a relatively low methylation ratio (< $50 \%)$. In particular, two CpG sites (-839 and -708) showed extremely low methylation ratios, and the observed ratio was maintained up to day 250 of gestation at these sites. The methylation levels increased at sites 820 and -813 by day 150 , and the hypermethylation status was maintained up to day 250 at these sites. The meth- ylation ratios at sites -326 and -197 decreased to half the values observed on day 60 . One specific site, -197 , exhibited a very low methylation ratio (only $10 \%$ ) on day 250 of gestation $(\mathrm{P}<0.05)$. A steady pattern of hypomethylation was observed at CpG sites $-839,-780$, and -708 throughout gestation.

The DNA methylation status of bCSHI and bPRPI in BTI bCSHI

Seven CpG sites in $b C S H 1$ regions 1 and 2 were analyzed by sodium bisulfate sequencing using BT-1 genomic DNA. A lower $(\mathrm{P}<0.05)$ methylation ratio was found at the -580 site in BT- 1 cells compared to the levels detected in bovine fibroblast cells (Figure 5A). 
(A)

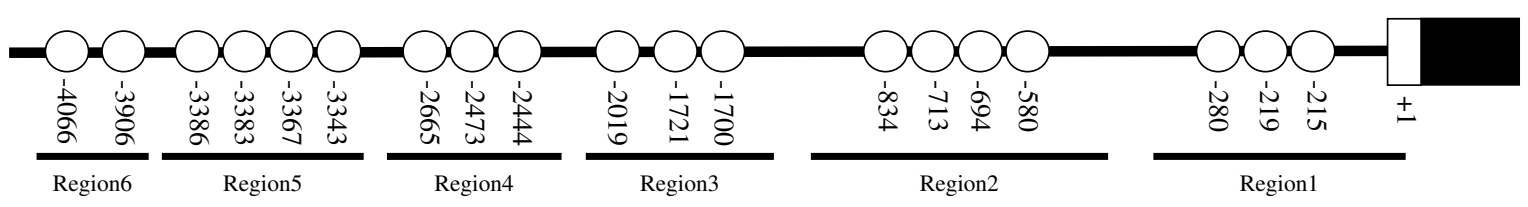

(B)

Fetal skin

Cotyledon

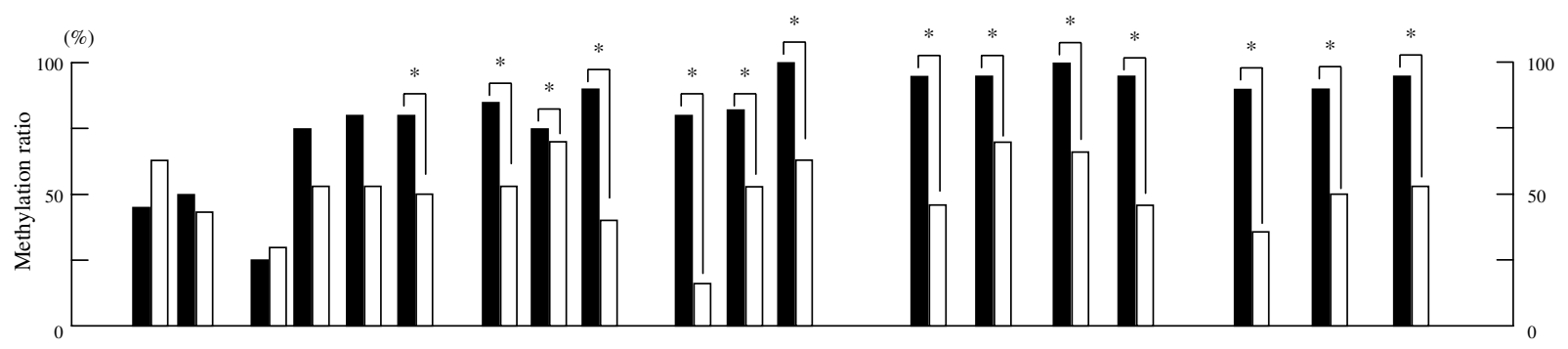

\section{Figure 2}

The detection of CpG sites and the methylation status of $b C S H I$ in placentomes on day 150 of gestation. (A) The location of $C_{P} G$ sites in the bCSHI 5'-flanking region. (B) The DNA methylation ratio of Day 150 COT $(n=3,10$ clones for each sample) and Day 150 SKIN samples $(n=2,15$ clones for each sample). The black bars indicate SKIN and the white bars depict COT samples. Values show the percentage total from 30 clones, and values marked with an asterisk(s) are significantly different $(* P<0.05)$.

\section{bPRPI}

Nine CpG sites in $b P R P 1$ regions 1 and 2 were analyzed by sodium bisulfate sequencing using BT-1 genomic DNA. Seven of the 9 CpG sites were hypermethylated in the BT1 cells (more than 50\%), and six out of the 9 sites were hypermethylated in the fibroblasts. The $-708,-470$, and 269 sites showed a higher $(\mathrm{P}<0.05)$ methylation ratio in the BT- 1 cells than in the fibroblasts. Whereas, the methylation rate at the CpG -326 site was lower $(\mathrm{P}<0.05)$ in the BT-1 cells (Figure 5B).

\section{The transcriptional activity in the 5 '-flanking region of the bCSHI and bPRPI genes}

bCSHI

The -213 $b$ CSH1 Luc construct had the highest transcriptional activity in the BT-1 (8.4 fold to the control) cells. The -368 and -599 Luc constructs had 4.1 and 7.3 fold higher activity relative to the no-promoter controls, respectively. A reduction in promoter activity was noted for the methylated $-368(\mathrm{P}<0.05)$ and -599 constructs in the BT-1 cells. The transcriptional activity of these constructs in fibroblasts was comparable: the $-213,-368$, and -599 constructs showed $11.8(\mathrm{P}<0.05), 7.9$, and 4.7 fold activity, respectively. In contrast, methylation of the -368 $(\mathrm{P}<0.05)$ and -599 constructs dramatically reduced the promoter activity (Figure 6A and 6B) in the fibroblasts.

\section{bPRPI}

The first two fragments of the 5 '-flanking region ( -50 and -80) demonstrated no transcriptional activity, in BT-1 or fibroblast cells. The highest activity in the BT- 1 cells was found with the -277 Luc construct (13.9 fold, $\mathrm{P}<0.05$ ), and increased activity was also found in the -510 (5.3 fold) and -860 (3.7 fold) constructs. Whereas, in the fibroblasts, only the -510 construct had a higher transcriptional activity than the control. Three methylated constructs from -277 to -860 displayed repressed transcription in both cell populations $(\mathrm{P}<0.05)$ (Figure 6C and 6D). 
(A)

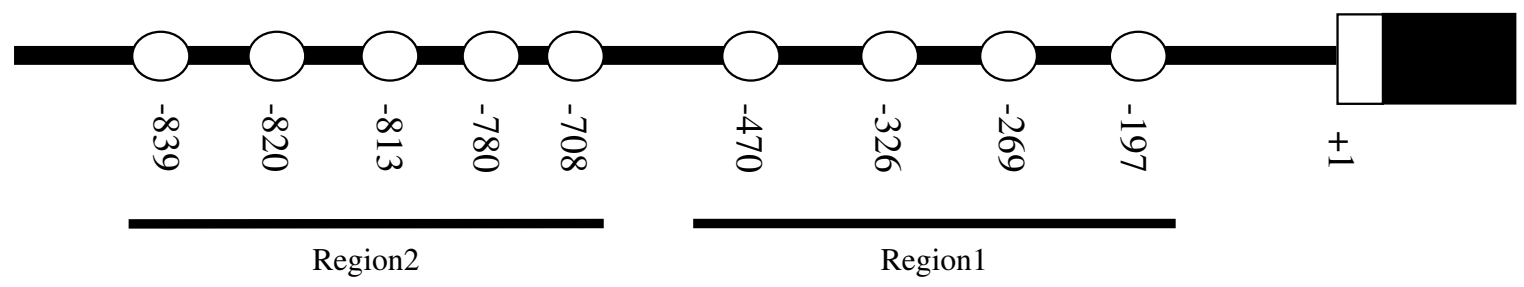

(B)

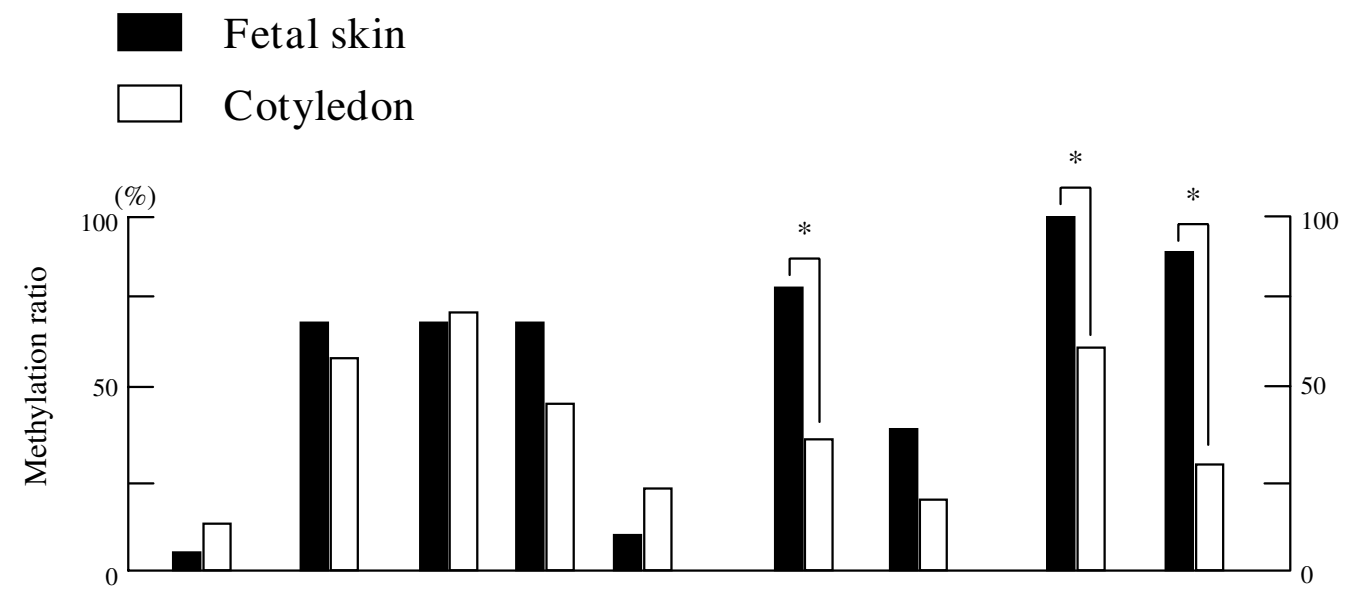

Figure 3

The detection of CPG sites and the methylation status of bPRPI in placentomes on day I50 of gestation. (A) The location of CPG sites in the bCSHI 5'-flanking region. (B) The DNA methylation ratio of Day I50 COT ( $\mathrm{n}=3$, I0 clones for each sample) and Day I50 SKIN samples ( $n=2$, I5 clones for each sample). The black bars indicate SKIN and the white bars depict COT samples. Values show the percentage total from 30 clones, and values marked with an asterisk(s) are significantly different $(* P<0.05)$.

\section{Discussion}

Cell to cell interactions are crucial to the development of the placenta and the exchange of stage-specific molecular signals between the fetal and maternal units $[5,6,17,18]$. Specifically, these interactions are paramount to programmed fetal growth, maternal adaptation to pregnancy, and coordination of parturition. Trophoblast-specific $\mathrm{BNC}$ is a source of an array of biochemical products including $b C S H 1$ and $b P R P 1[17,18]$. The expression profiles of $b C S H 1$ and $b P R P 1$ are dynamically distinct during gestation, which suggests an intrinsic regulatory role in placental formation and fetal growth in cattle [17-19]. Although, $b C S H 1$ and $b P R P 1$ stem from the same BNC, the mechanism by which endogenous mediators regulate the transcription and translation of these transcripts remains to be established [17]. The stage-specific differen- tial gene expression may be directly or indirectly regulated by transcription factors [26]; however, recent studies have established that epigenetic regulation, particularly DNA methylation, is an important mode of control [27-34]. Here, we show evidence of epigenetic regulation of the $b C S H 1$ transcript in bovine trophoblasts.

Treatment of bovine fibroblasts with 5-aza-dC induced an increase in the level of $b \mathrm{CSH} 1$ expression in parallel with a decrease in the expression of $b P R P 1$. Ectopic expression of $b C S H 1$ in endometrial fibroblasts and subsequent sequence analysis following 5 -aza-dC supplementation provided proof of the concept as well as the practicality of the technique, as has been described for other genes [2734]. Interestingly, the expression of $b C S H 1$ was restricted to BNC and could not be induced in fibroblasts, including 
(A)

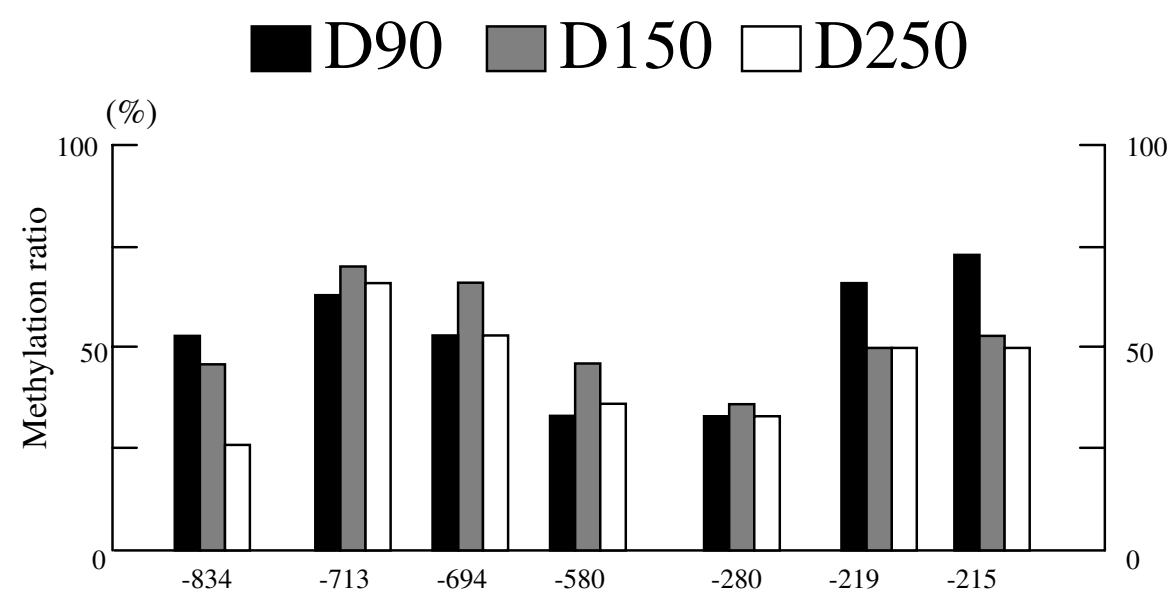

(B)

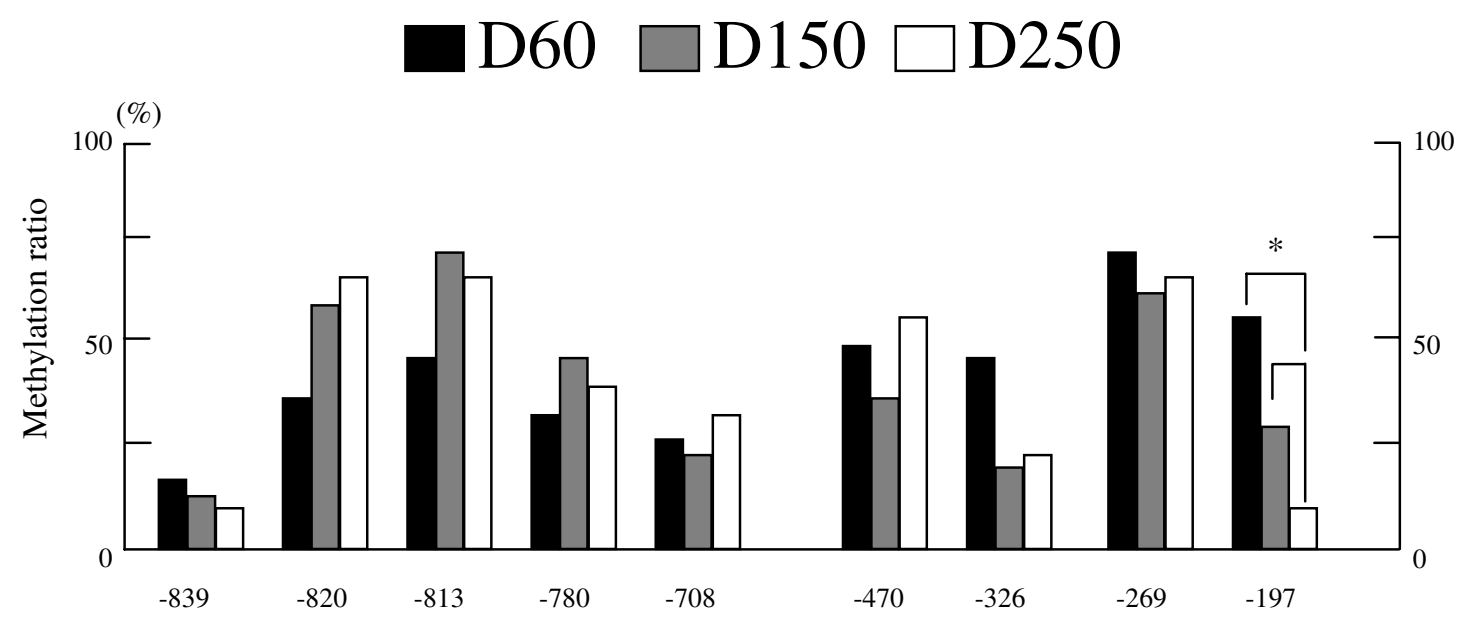

Figure 4

The dynamic methylation status of $b C S H I$ and $b P R P I$ in placentomes. (A) The dynamic DNA methylation ratios at each site in bCSHI. The black bar indicates Day 90 COT, the gray bar Day I50 COT, and the white bar Day 250 COT. (B) The dynamic DNA methylation ratios at each site in BPRPI. The black bar indicates Day 60 COT, the gray bar Day I50 COT, and the white bar Day 250 COT. Values show the percentage total from 30 clones ( $n=3,10$ clones for each sample), and values marked with an asterisk $(s)$ are significantly different $(* \mathrm{P}<0.05)$.

COT fibroblasts (data not shown), implying that the source of the cells as well as the cell microenvironment influences mRNA expression. Additionally, the impact of the length and position of methylation zones may be unique for each gene, and the influence of 5-aza-dC may be quenched depending on the cell/gene milieu. In con- trast, compelling evidence obtained over the past decade has demonstrated that histone acetylation is linked to transcriptional activation [30]. Studies involving the Nanog gene, which is a key factor in maintaining the pluripotency of stem cells, revealed that its expression is not affected by 5 -aza-dC; however, a combination treat- 


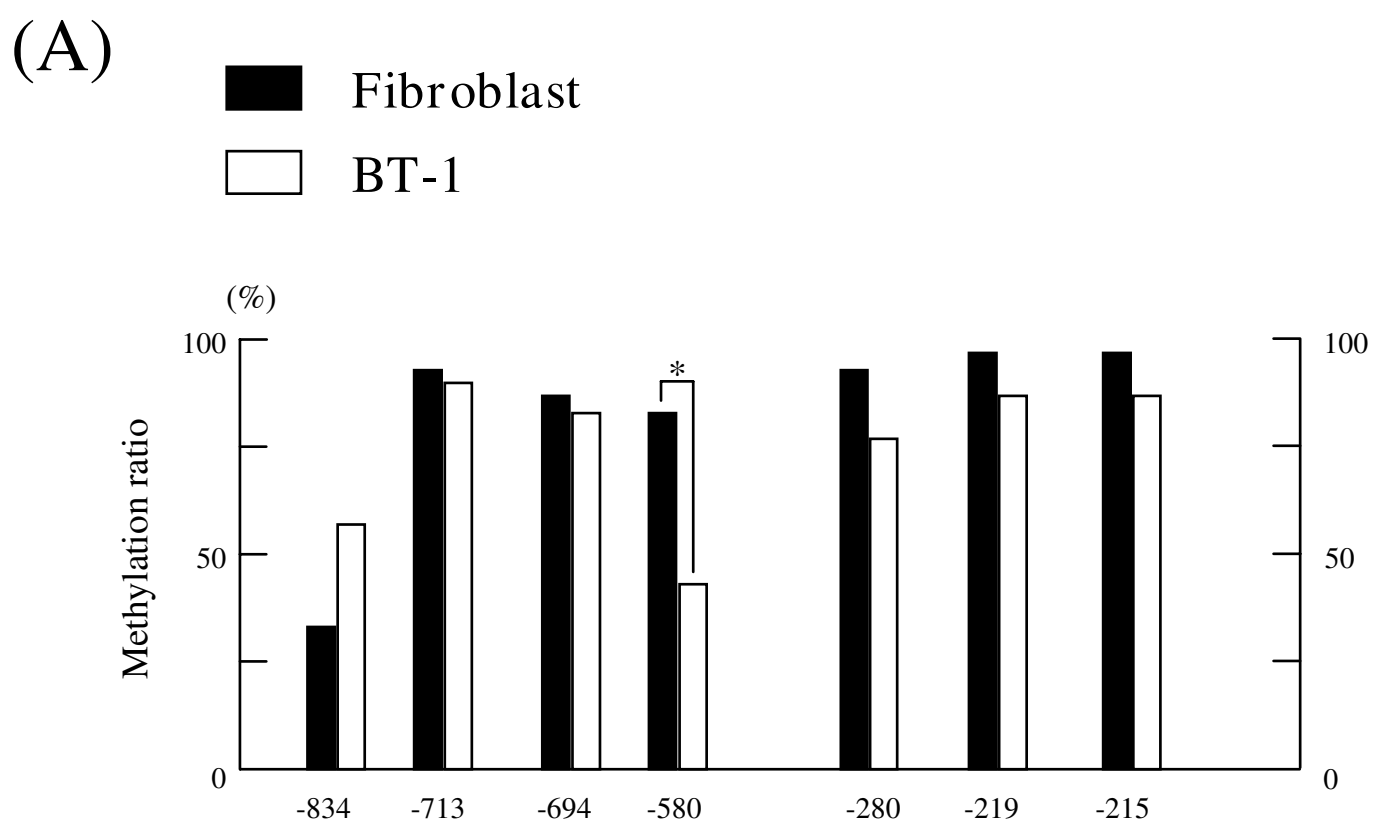

(B)

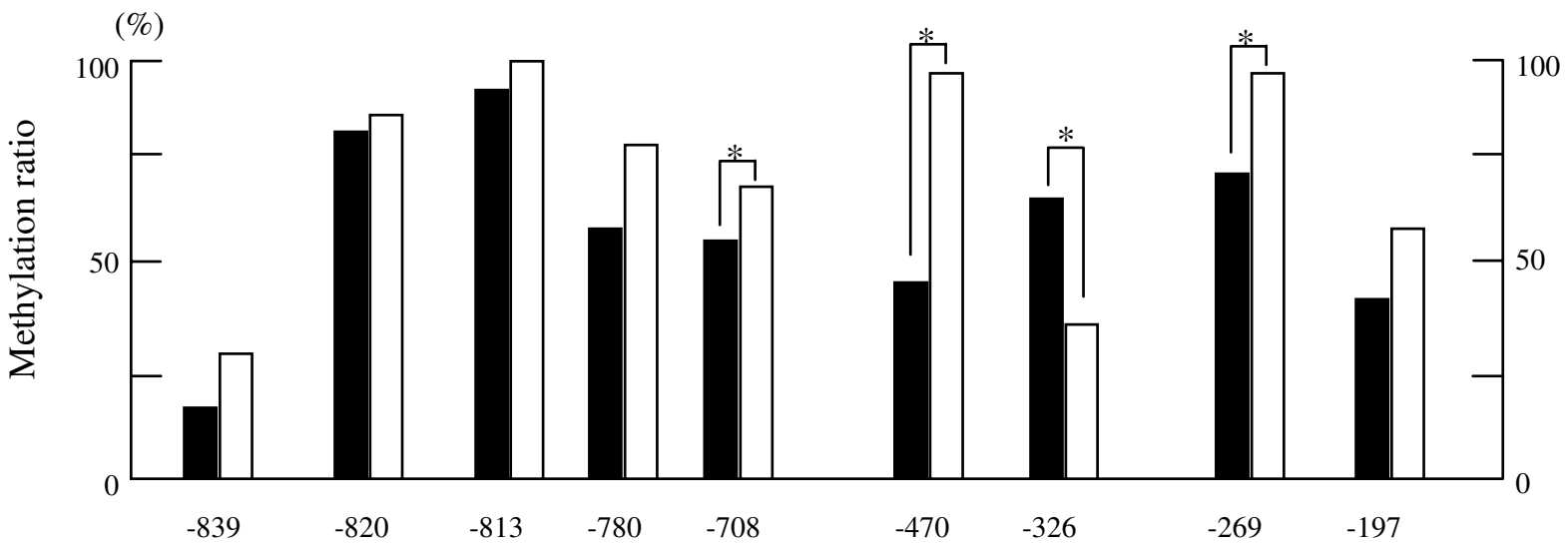

Figure 5

The DNA methylation status of $b C S H I$ and $b P R P I$ in BT-I cells. The DNA methylation ratios of BT-I and cotyledonary fibroblast cells in (A) bCSHI and (B) bPRPI. The black bar indicates cotyledonary fibroblast cells, and the white bar depicts BT-I cells. The values show the percentage total from 30 clones, and values marked with an asterisk(s) are significantly different $(* P<0.05)$.

ment including trichostatin A facilitated expression [30]. This indicates that gene transcription is intricately regulated by a functional link between DNA methylation and histone acetylation. In this study, we did not examine the biological role of histone acetylation in relation to $b C S H 1$ and $b P R P 1$ regulation, and this remains to be clarified. Although the precise regulation of $b C S H 1$ and $b P R P 1$ remains obscure, our study provides the first evidence of a methylation-based regulatory mechanism for bovine PLrelated transcripts.

We envisioned that a number of $\mathrm{CpG}$ islands in the 5'flanking region of $b C S H 1$ will be hypomethylated in the COT, taking into account that the $b C S H 1$ gene is a tro- 


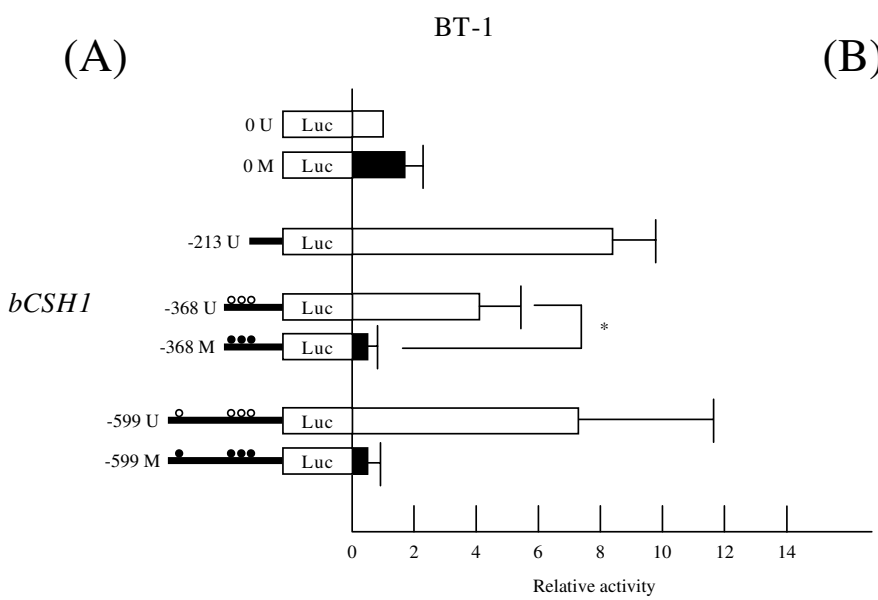

(B)

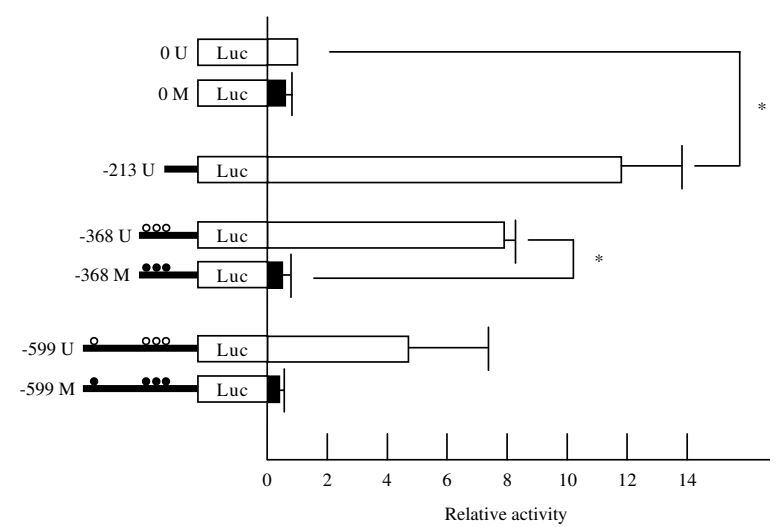

(C)

(D)
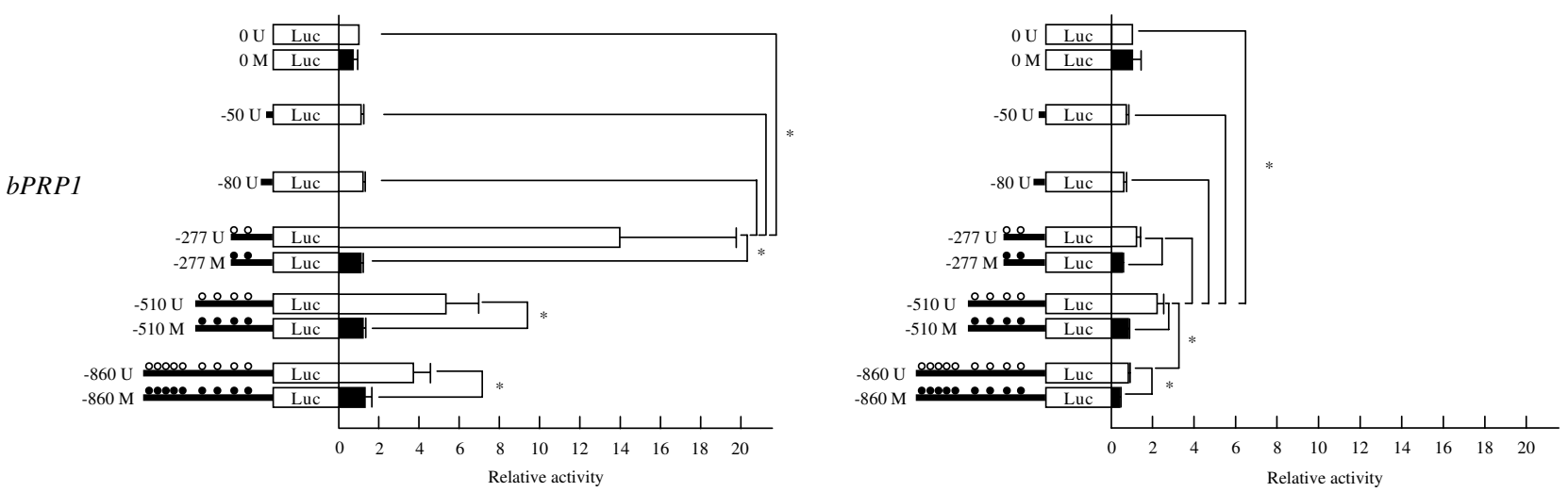

Figure 6

The transcriptional activity of bCSHI and bPRPI constructs in BT-I cells and fibroblasts. The transcriptional activity of $B T-I$ cells $(A, C)$ and bovine fibroblast cells $(B, D)$. $(A)$ and $(B)$ show that of $b C S H I$, while $(C)$ and $(D)$ show that of $b P R P I$. The left figures show constructs, the horizontal lines indicate the length of the constructs, and the circles indicate the $C_{p} G$ sites. "M" and the black circles indicate methylated constructs, and " $\mathrm{U}$ " and white circles indicate unmethylated constructs. The values are shown as the mean $\pm \operatorname{SEM}(n=3)$, and values marked with an asterisk $(\mathrm{s})$ are significantly different $(* P<0.05)$.

phoblast-specific transcript [17]. On the other hand, we predicted that the majority of CpG sites associated with bCSH1 in somatic cells, such as SKIN will likely be hypermethylated. The bisulfite sequencing confirmed the above notion, particularly, the results from the day 150 samples (Figure $2 \mathrm{~B}$ ). We further demonstrated that the methylation status of $b P R P 1$ is distinct from that of $b C S H 1$. Generally, the methylation pattern of both genes mirrored their expression profiles throughout gestation, particularly at the -197 site of $b P R P 1$. However, it remains to be elucidated whether the changes observed in the methylation levels of both genes are to some extent dependant on the proportion of somatic versus trophoblast cells in placentomes throughout the various stages of gestation.
Hence, it is important to delineate the stage-specific regulatory role of methylation patterns in relation to cell populations to facilitate interpretations of the activation/ suppression of trophoblast-specific transcripts. On the other hand, we only detected three CpG sites of bPRP1 that were significantly different between the COT and SKIN samples at day 150 (Figure 3B). The biological significance of the variation in the methylation levels observed between the fibroblast cells and SKIN at day 150 is not clear. However, these differences could be attributable to their divergent expression patterns during gestation [5]. Additionally, the evidence from in-vitro cultures of HeLa cells indicates that the DNA methylation pattern undulates during the cell cycle of a mature somatic cell 
[35]. Therefore, the likelihood of some dynamic alterations in global methylation levels with progressive subcultures of fibroblasts needs verification.

During gestation, $b$ CSH1 expression continuously increases with the progression of gestation, while $B P R P 1$ also increases up to mid-gestation followed by a steady decline $[19,20]$. The question is what controls this disparate pattern of expression of these co-expressed molecules. Accordingly, we first confirmed the transcriptional activities of both genes and detected no marked difference in bCSH1 activation between the BT-1 cells and bovine fibroblast cells. Similarly, unmethylated $b P R P 1$ constructs retained activity in both cell lines. Notably, the levels of bPRP1 transcriptional activity for the individual constructs were different between the fibroblasts and BT-1 cells. Also, the unmethylated $b P R P 1$ constructs had lower transcriptional activity, while the methylated constructs augmented suppression. Although these results indicate that the expression of both genes is affected by their methylation status, other factors may be participating in their regulation, such as, histone acetylation or ubiquitination and/or transcription factors $[27,30,36,37]$. In this study, the efficiency of the transfection constructs in BT-1 cells was lower than that in the fibroblast cells (data not shown). So the efficiency of transfection may be affected by the intensity of luciferase activity, and more effective transfection methods need to be developed for precise analysis of luciferase activity. The DNA sequences of the 5 '-flanking region in bovine and ovine (o)CSH1 are highly conserved, and the binding site of AP-2 was detected in $b C S H 1$ as a consensus cis-element that is similar to the cis-element $(-58 \mathrm{bp})$ that has been recognized in $o$ CSH1 $[3,25,38]$. Furthermore, Sp1 $(-220$ to -215$)$ and GATA ( -475 to -470 , and -105 to -99 ) consensus binding sites exist within the -599 region, which was confirmed by GENETYX Ver.8 (Genetyx, Tokyo, Japan). These binding sites might interact with AP-2, as these transcriptional factors are documented to regulate some placental specific genes [24-26,28,39-41]. To date, there are no reports concerning the interplay between transcriptional factors and bPRP1, but AP-2 may be a regulatory factor since its expression profile in bovine placenta parallels that of bPRP1 [26]. Ushizawa et al. [26] reported two AP-2 consensus binding sites in the upstream region within -200 (44 to -33 and -74 to -63 ), but surprisingly in this study, the constructs containing these two sites showed no transcriptional activity in either the BT-1 or fibroblast cells. Therefore, the role of the above sites in transcription regulation needs further elucidation [26]. In the present study, we detected a new AP-2 consensus binding site (267 to -260 ) using GENETYX Ver.8, and the constructs containing these sites, $-860,-510$, and -277 , exhibited high $b P R P 1$ transcriptional activity in BT-1 cells. Therefore, it is plausible that AP-2 is involved in the transcriptional regulation of $b P R P 1$. Additionally, Sp1 (-270 to -265$)$ and GATA (-84 to -79$)$ consensus binding sites were also detected in the upstream region of $b P R P 1$ by GENETYX Ver.8 analysis. This likely denotes combinatorial regulation of the transcriptional activation and/or suppression of $b P R P 1$.

In summary, our findings demonstrate that DNA methylation may regulate dynamic changes in gene expression during BNC morphogenesis, placental formation, and trophoblast differentiation in bovine species. However, further studies are necessary to understand the precise transcriptional regulatory mechanisms of $b C S H 1$ and bPRP to comprehend their role in placentogenesis, fetogenesis, maternal recognition and adjustment to pregnancy, and coordination of parturition. This may also provide an insight into the roles of the various homologous and orthologous members of the GH/PRL family that are detected in the placenta.

\section{Conclusion}

Our data indicates for the first time that there are different regulatory mechanisms for the $b C S H 1$ and $b P R P 1$ genes and demonstrates that $b C S H I$ may be subject to transcriptional regulation by DNA methylation. These data unravel the novel kinetics of the induction of the synchronously expressed BNC-specific $b C S H 1$ and bPRP1 transcripts, which may aid the understanding of the intricate regulation and the specific role(s) of these important molecules in bovine placentogenesis and the progression of pregnancy.

\section{Methods \\ Animals and tissue collection}

Placental cotyledonary villi (COT) and fetal skin (SKIN) were collected from Japanese black cows. The artificial insemination day was designated as day 0 of gestation. The tissues collected across specific stages of gestation were designated as follows: (i) Day 60: COT samples were collected from three different cows on days 54, 64, and 65 of gestation ( $\mathrm{n}=3$ animals for bisulfite sequencing of bPRP1); (ii) Day 90: COT samples were collected on days 87,88 , and 97 ( $\mathrm{n}=3$ animals for bisulfite sequencing of bCSH1); (iii) Day 150: COT samples were collected on days $144(\mathrm{n}=2$ animals) and $150(\mathrm{n}=3$ animals for bisulfite sequencing), and SKIN samples were collected from both animals ( $\mathrm{n}=2$ animals for bisulfite sequencing) and designated as Day 150 SKIN; and (iv) Day 250: COT samples were collected on days 245, 249, and 252 (n $=3$ animals for bisulfite sequencing). The collected samples were stored at $-80^{\circ} \mathrm{C}$ prior to DNA extraction. All procedures for these animal experiments were carried out in accordance with guidelines approved by the Animal Committee of Iwate University and the National Institute of Agrobiological Sciences for the use of animals. 


\section{Cell culture}

BT-1 cells established from in vitro blastocysts $[42,43]$ were cultured according to a previously described method [44]. Briefly, the cells were cultured in Dulbecco's modified Eagle's medium/F-12 medium (DMEM/F-12, Sigma, Saint Louis, MI, USA) containing $100 \mathrm{IU} / \mathrm{ml}$ of penicillin and $100 \mu \mathrm{g} / \mathrm{ml}$ of streptomycin (Sigma) supplemented with 10\% fetal bovine serum (FBS, HANA-NESCO, Tokyo, Japan) at $37^{\circ} \mathrm{C}$ in an atmosphere of $5 \% \mathrm{CO}_{2}$. The medium was changed every two or three days. A monolayer of confluent BT-1 cells was mechanically passaged by pipetting. The dissociated cell clumps in the medium were plated on collagen-coated flasks. The cell clumps attached themselves to the flasks and proliferated to re-form a monolayer. Successful passages were also achieved by transferring multicellular vesicles that had spontaneously formed from the cell colony. Bovine endometrial or cotyledonary fibroblast cells, which had been derived from the uteruses of Japanese black cattle and established as detailed elsewhere [45], were cultured in DMEM/F-12 (sigma) containing $100 \mathrm{IU} / \mathrm{ml}$ of penicillin and $100 \mu \mathrm{g} /$ ml of streptomycin (Sigma) supplemented with 10\% FBS (HANA-NESCO) at $37^{\circ} \mathrm{C}$ in an atmosphere of $5 \% \mathrm{CO}_{2}$. In this study, 4th passaged endometrial fibroblast cells or 9th passaged cotyledonary fibroblast cells were used. The medium was changed every two to three days. A monolayer of confluent fibroblast cells was passaged and scaled down using $0.25 \%$ Trypsin-EDTA (Sigma) and plated on flasks.

\section{5-aza-2'-deoxycytidine treatment}

A confluence of 30-40\% of bovine endometrial fibroblast cells or cotyledonary fibroblast cells was plated on a 100$\mathrm{mm}$ dish and incubated for $24 \mathrm{~h}$. Then, the cells were treated with either vehicle or $10 \mu \mathrm{M} 5$-aza-2'-deoxycytidine (5-aza-dC) in an FBS-containing medium for $72 \mathrm{~h}$. The medium and 5-aza-dC were changed every $24 \mathrm{~h}$. The BT-1 cells were treated as described above.

Total RNA was isolated from the cultured cells using TRIzol Reagent (Invitrogen, Carlsbad, CA, USA) according to the manufacturer's instructions. The RNA concentration was calculated by measuring the absorbance with a spectrophotometer (U-2000A, HITACHI, Tokyo, Japan). All RNA samples were stored at $-80^{\circ} \mathrm{C}$ prior to processing.

\section{RT-PCR}

One microgram of total RNA was reverse transcribed into cDNA with a Random Primer (TOYOBO, Osaka, Japan) and Superscript III reverse transcriptase (Invitrogen). PCR was performed using AmpliTaq Gold DNA polymerase (Applied Biosystems, Foster City, CA, USA). The annealing temperature was $60^{\circ} \mathrm{C}$, and the PCR involved 35 cycles. The PCR products were analyzed by agarose gel electrophoresis and visualized by ethidium bromide staining. The respective primer sets for $b C S H 1, b P R P 1$, and GAPDH are listed in Table 1. All the primers were designed using Primer 3 [46] and commercially synthesized (Greiner, Tokyo, Japan). The PCR products were extracted from agarose gel and purified using a GENECLEAN III Kit (MP Biomedicals, Solon, OH, USA). The purified PCR products were ligated to the pGEM-T Easy vector (Promega, Madison, WI, USA) and amplified in $\mathrm{DH}-5 \alpha$ (Invitrogen). All plasmids were purified using the QIAprep Spin Miniprep Kit (QIAGEN, Valencia, CA, USA) and sequenced using an ABI Prism 3100 automatic sequencer (Applied Biosystems).

Table I: The Oligonucleotide primers used for the RT-PCR and quantitative real-time RT-PCR.

\begin{tabular}{|c|c|c|c|}
\hline Gene & Strand & Sequence & Position \\
\hline \multicolumn{4}{|l|}{ RT-PCR } \\
\hline \multirow{2}{*}{$\begin{array}{c}b C S H I \\
\left(N M \_|8| 007\right)\end{array}$} & Forward & 5'-CTGCTGGTGGTGTCAAATCTAC-3' & $|70-19|$ \\
\hline & Reverse & 5'-TGGTTGGGTTAATTGTGGGC-3' & $828-812$ \\
\hline \multirow{2}{*}{$\begin{array}{c}\text { bPRPI } \\
\text { (NM_I74I59) }\end{array}$} & Forward & 5'-CACGGTCAACAGGAGTCCTCACC-3' & $43-65$ \\
\hline & Reverse & 5'-AATTTCAGGTAGCCCGCTGTGG-3' & $873-852$ \\
\hline \multirow{2}{*}{$\begin{array}{c}\text { GAPDH } \\
\left(\mathrm{NM} \_001034034\right)\end{array}$} & Forward & 5'-CCTTCATTGACCTTCACTACATGGTCTA-3' & $173-200$ \\
\hline & Reverse & 5'-GCTGTAGCCAAATTCATTGTCGTACCA-3' & $1029-1003$ \\
\hline \multicolumn{4}{|l|}{ real-time RT-PCR } \\
\hline \multirow[t]{2}{*}{$b \mathrm{CSHI}$} & Forward & 5'-GCAACATTGGTGGCTAGCAA-3' & $281-300$ \\
\hline & Reverse & 5'-GCCCTCGCCAAACTGTTTATTA-3' & $358-337$ \\
\hline \multirow[t]{2}{*}{ bPRPI } & Forward & 5'-CACGGAGCTGCAGCATATGA-3' & $50 I-520$ \\
\hline & Reverse & 5'-CCTTGTGGCGCTTGATAGGA-3' & $558-539$ \\
\hline \multirow{2}{*}{ GAPDH } & Forward & 5'-AAGGCCATCACCATCTTCCA-3' & 280-299 \\
\hline & Reverse & 5'-CCACCACATACTCAGCACCAGCAT-3' & $355-332$ \\
\hline
\end{tabular}




\section{Quantitative real-time RT-PCR}

Real-time RT-PCR was performed using the SYBR Green Detection System (Applied Biosystems) according to the method described previously [26]. PCR and the resulting increase in reporter fluorescent dye emission were monitored in real time using a 7300 Real Time PCR System (Applied Biosystems). The primer pair was designed by the Primer Express Program (Applied Biosystems). The primers for each gene are listed in Table 1 . The thermal cycling conditions included one cycle at $50^{\circ} \mathrm{C}$ for $2 \mathrm{~min}$, one cycle at $95^{\circ} \mathrm{C}$ for $10 \mathrm{~min}$, and 40 cycles at $95^{\circ} \mathrm{C}$ for 15 $\mathrm{s}$ and $60^{\circ} \mathrm{C}$ for $1 \mathrm{~min}$. To quantify the mRNA concentrations, standard curves were generated for each gene by serial dilution of the plasmids containing their cDNA. The expression ratio of each gene was normalized relative to the abundance of a validated endogenous control GAPDH mRNA to adjust for variations in the RT-PCR reaction. Quantitation was performed using three separately cultured samples per condition, and all values are presented as mean \pm SEM.

\section{Genomic DNA extraction}

The genomic DNA was extracted from COT, SKIN, and cultured cells using a Puregene DNA Purification System (Gentra Systems, Minnesota, U.S.A.) according to the manufacturer's instructions. The DNA concentration was calculated by a spectrophotometer. All DNA samples were stored at $-30^{\circ} \mathrm{C}$ prior to processing.

\section{Preparing constructs for sequencing and luciferase reporter assays}

The sequence of the 5'-flanking regions of $b C S H 1$ and bPRP1 was confirmed by cloning them. Each fragment of the $b C S H 1$ and $b P R P 1$ regions was amplified using PCR with primers designed on Map Viewer, which is available on the NCBI web site [47]. Each PCR was performed using KOD-Plus-Ver.2 (TOYOBO). The primer sets used are listed in Tables 2 and 3. The annealing temperature was set at 62 to $65.5^{\circ} \mathrm{C}$, and the PCR lasted 30 cycles. The PCR products were analyzed by agarose gel electrophoresis and visualized by ethidium bromide staining. The PCR products were cut by Kpn I (TOYOBO) and Xho I (TOYOBO), or Sac I (TOYOBO) and Xho I, before being cloned into the pGL3-Basic vector (Promega) using a DNA Ligation
Kit Ver.2.1 (TaKaRa, Tokyo, Japan). All constructs were amplified in SCS110 (Stratagene, La Jolla, CA, USA), which lacks two methylases (dcm and dam), and sequenced using an ABI Prism 3100 automatic sequencer (Applied Biosystems) [30].

\section{Sodium bisulfite genomic sequencing}

CpG methylation status was examined at each stage of gestation (Day 90 COT, Day 150 COT, Day 250 COT, and Day 150 SKIN for $b C S H 1$; Day 60 COT, Day 150 COT, Day 250 COT, and Day 150 SKIN for bPRP1) as well as in cultured cells (BT-1 and bovine fibroblast cells) by sodium bisulfite genomic sequencing analysis. The details of the sodium bisulfite genomic sequencing are contained in previous reports [32,33]. Briefly, DNA $(1 \mu \mathrm{g})$ digested with EcoRI (for $b C S H 1$ ) or BamHI (for $b P R P 1$ ) was denatured in $0.3 \mathrm{M} \mathrm{NaOH}$ at $37^{\circ} \mathrm{C}$ for $15 \mathrm{~min}$. Then, $3.6 \mathrm{M}$ sodium bisulfite ( $\mathrm{pH} 5.0$ ) and $0.6 \mathrm{mM}$ hydroquinone were added, and the sample underwent 15 cycles of $30 \mathrm{~s}$ denaturation at $95^{\circ} \mathrm{C}$ and $15 \mathrm{~min}$ of incubation at $50^{\circ} \mathrm{C}$. The sample was desalted using the Wizard DNA Clean-up system (Promega) and desulfonated in $0.3 \mathrm{M} \mathrm{NaOH}$. DNA was ethanol precipitated and dissolved in $40 \mu \mathrm{l}$ of Tris-EDTA buffer. All modified DNA samples were stored at $-80^{\circ} \mathrm{C}$ prior to processing.

The DNA fragments were amplified with bisulfite PCR using AmpliTaq Gold (Applied Biosystems) and the set of primers described in Tables 4 and 5. The primer design was performed using MethPrimer [48]. The annealing temperature was set at 56 to $62^{\circ} \mathrm{C}$, and the total number of cycles was 35 . The PCR products were analyzed by agarose gel electrophoresis and visualized by ethidium bromide staining. The PCR products were cloned into a pGEM-T Easy vector (Promega). Ten clones from COT and 15 clones from SKIN for each sample and region (calculated as total 30 clones per region) were sequenced using an ABI Prism 3100 automatic sequencer (Applied Biosystems), and the methylation ratios of the samples were determined. Thirty clones from cultured cells from each sample and region were sequenced using an ABI Prism 3100 automatic sequencer. All results are shown as percentages.

Table 2: The primers used for the bCSHI (NW_00I494I8I) 5'-flanking region of the sequencing and reporter constructs.

\begin{tabular}{ccccc}
\hline Position & Strand & Sequence & Annealing \\
\hline-4090 to -4073 & Forward & 5'-ATGGTACCATTGTCTATTACAGGGTGCA-3' & 65.5 \\
-599 to -581 & Forward & 5'-GGGGTACCCCTGTCCTAGTTCTTTAAC-3' & 64 \\
-368 to -353 & Forward & 5'-GGGGTACCCCTTAGATCTCTGAGTAG-3' & 62.6 \\
-213 to -194 & Forward & 5'-GGGGTACCCCATAGGGTGTATACAGATAC-3' & 62 \\
-8 to +8 & Reverse & 5'-ATCTCGAGATGGGAATGCCTAAGGAG-3' &
\end{tabular}

a All forward primers have a Kpnl recognition site (-GGTACC-), and the reverse primer has an Xhol recognition site (-CTCGAG-) at its 5'-end. b The reverse primer is common to all PCRs. 
Table 3: The primers used for the bPRPI (AH00I I53) 5'-flanking region of the sequencing and reporter constructs.

\begin{tabular}{|c|c|c|c|}
\hline Position & Strand & Sequence & Annealing \\
\hline-860 to $-845^{a}$ & Forward & 5'-GGGAGCTCCCTGTAAAATATCATGTA-3' & 62 \\
\hline-510 to $-495^{a}$ & Forward & 5'-GGGAGCTCCCATTAATACCAACACAG-3' & 62 \\
\hline-277 to $-262^{a}$ & Forward & 5'-GGGAGCTCCCGACTCCTCCGCCCATG-3' & 62 \\
\hline-80 to $-65^{b}$ & Forward & 5'-GGGGTACCCCAGCTCTACTCCACAGG-3' & 65.5 \\
\hline-50 to $-35 b$ & Forward & 5'-GGGGTACCCCTTTTATGGCCTCATGG-3' & 65.5 \\
\hline+23 to $+38 \mathrm{c}$ & Reverse & 5'-ATCTCGAGATGGGAATGCCTAAGGAG-3' & \\
\hline
\end{tabular}

a The primers have a Sacl recognition site (-GAGCTC-). ${ }^{b}$ The primers have a Kpnl recognition site (-GGTACC-). ${ }^{\mathrm{c}}$ The common reverse primers for all forward primers have an Xhol recognition site (-CTCGAG-) at their 5'-end.

\section{In vitro methylation of constructs}

The constructs for the luciferase reporter assay were methylated in vitro by SssI CpG methylase (New England BioLabs) in the presence of $160 \mu \mathrm{M}$ of S-adenosylmethionine at $37^{\circ} \mathrm{C}$ for $3 \mathrm{~h} \mathrm{[30].} \mathrm{Completion} \mathrm{of} \mathrm{the} \mathrm{methylation}$ reaction was confirmed when digestion with Hha I was no longer possible [49].

\section{Luciferase reporter assay}

The constructed plasmids with or without methylation were transfected into BT-1 using ExGen 500 in vitro Transfection Reagent (Fermentas, Hanover, USA) and bovine fibroblast cells using FuGENE 6 (Roche Diagnostics, Basel, Switzerland). After 10 days of passaging, the BT-1 cells were transfected with $5 \mu \mathrm{g}$ of constructs and $50 \mathrm{ng}$ of pRL-TK (Promega), and cultured in the conditions detailed above for $72 \mathrm{~h}$. Bovine fibroblast cells were transfected with $200 \mathrm{ng}$ of constructs and 2 ng of pRL-TK and cultured in the conditions described above for $48 \mathrm{~h}$. The luciferase activity was measured by a TR-717 Microplate Luminometer (Applied Biosystems) [50]. The activity of all constructs was determined using a Dual-Luciferase Reporter Assay System (Promega) according to the manufacturer's instructions. Assays were performed three times, and all results are shown as the mean \pm SEM.

\section{Statistic analysis}

The Student's t-test and Pearson's chi-square test were used to analyze the statistical differences between the 5aza-dC supplemented and non-supplemented samples and the sodium bisulfite treated genomic sequences, respectively. Differences among luciferase reporter constructs were assessed by one-way ANOVA, followed by the Tukey-Kramer multiple comparison test. Differences were considered significant at $\mathrm{P}<0.05$.

\section{Authors' contributions}

YN participated in the design of the study, carried out most of the experiments, and wrote the manuscript. KK participated in coordinating the design of the study. TT supplied the tissue samples. OVP participated in the discussion and provided insights into the manuscript. $\mathrm{KH}$ planned and participated in coordinating the design of the study, contributed to drafting the manuscript, and supervised the process. All authors have read and approved the final manuscript.

\section{Acknowledgements}

We thank Kumiko Sugawara for her technical assistance. This study was supported by a Research Project for Utilizing Advanced Technologies (051770) grant from the Ministry of Agriculture, Forestry, and Fisheries of Japan; a grant (Kiban-kenkyu B 17380 I72) from the Ministry of Education, Culture, Sport, Science, and Technology of Japan; and a grant from the Ani-

Table 4: The primers used for the bisulfite sequencing of $b C S H I$.

\begin{tabular}{|c|c|c|c|}
\hline Region & Strand & Sequence & Annealing \\
\hline \multirow[t]{2}{*}{ Region I } & Forward & 5'-AGGGAAGATTTTTTTGGAGAAGG-3' & 60 \\
\hline & Reverse & 5'-AATAATAACCTTCAAATAACCAATACAC-3' & \\
\hline \multirow[t]{2}{*}{ Region 2} & Forward & 5'-AAGAGTTTGTATGGATTTTTTTAGA-3' & 60 \\
\hline & Reverse & 5'-ССАСАСТСТТССТСАATAATAATAA-3' & \\
\hline \multirow[t]{2}{*}{ Region 3} & Forward & 5'-TTTGATAATTGTTTATTGAATGATTTATTA-3 & 60 \\
\hline & Reverse & 5'-САAАТTСАСТССТААССТАТСТТТТСТ-3' & \\
\hline \multirow[t]{2}{*}{ Region 4} & Forward & 5'-AGTTTGTTAATAAATGAATTTTTTTTT-3' & 56 \\
\hline & Reverse & 5'-СТTAСТTTTТССТСТTTTСТАСССТАAA-3' & \\
\hline \multirow[t]{2}{*}{ Region 5} & Forward & 5'-GTTTGGGGTTGAATATTTATTATT-3' & 60 \\
\hline & Reverse & 5'-TACCTACTTCTATTTAATACCAATT-3' & \\
\hline \multirow[t]{2}{*}{ Region 6} & Forward & 5'-ATGTTGTTTATTATAGGGTGTATA-3' & 56 \\
\hline & Reverse & 5'-TTATATCTTTTACAATTTTAATACTAA-3' & \\
\hline
\end{tabular}


Table 5: The primers used for the bisulfite sequencing of bPRPI.

\begin{tabular}{lll}
\hline Region & Strand & Sequence \\
Region 1 & Forward & '5'-GGGATTGTTGTTGTTGTTGTTAAGT-3' \\
& Reverse & 5'-AAAACTATCTCTTTCTCCATACTAATACCT-3' \\
Region 2 & Forward & 5'-TTGTGTATGAGATAGTAAAAGAGATATTGA-3' \\
& Reverse & 5'-CAATAAAAAACCAAAAAAACTATAATTACA-3'
\end{tabular}

mal Remodeling Project $(05-201,202)$ of the National Institute of Agrobiological Sciences.

\section{References}

I. Schuler LA, Shimomura K, Kessler MA, Zieler CG, Bremel RD: Bovine placental lactogen: molecular cloning and protein structure. Biochemistry 1988, 27:8443-8448.

2. Schuler LA, Hurley WL: Molecular cloning of a prolactin-related mRNA expressed in bovine placenta. Proc Natl Acad Sci USA 1987, 84:5650-5654.

3. Kessler MA, Schuler LA: Structure of the bovine placental lactogen gene and alternative splicing of transcripts. DNA Cell Biol 1991, 10:93-104.

4. Schuler LA, Kessler MA, Tanaka M, Nakashima K: Nomenclature clarification for the bovine placental prolactin-related hormones. Endocrinology 1991, I 29(4):2057.

5. Ushizawa $\mathrm{K}$, Kaneyama $\mathrm{K}$, Takahashi $\mathrm{T}$, Tokunaga $\mathrm{T}$, Tsunoda $\mathrm{Y}$, Hashizume K: Cloning and expression of a new member of prolactin-related protein in bovine placenta: bovine prolactin-related protein-VII. Biochem Biophys Res Commun 2005, 326:435-44I.

6. Ushizawa K, Takahashi T, Hosoe M, Kaneyama K, Hashizume K: Cloning and expression of two new prolactin-related proteins, prolactin-related protein-VIII and -IX, in bovine placenta. Reprod Biol Endocrinol 2005, 3:68.

7. Larson JH, Kumar CG, Everts RE, Green CA, Everts-van der Wind A, Band MR, Lewin HA: Discovery of eight novel divergent homologs expressed in cattle placenta. Physiol Genomics 2006, 25:405-4I3

8. Colosi P, Talamantes F, Linzer DI: Molecular cloning and expression of mouse placental lactogen I complementary deoxyribonucleic acid. Mol Endocrinol 1987, I I:767-776.

9. Jackson LL, Colosi P, Talamantes F, Linzer DI: Molecular cloning of mouse placental lactogen cDNA. Proc Natl Acad Sci USA 1986, 22:8496-8500.

10. Robertson MC, Croze F, Schroedter IC, Friesen HG: Molecular cloning and expression of rat placental lactogen-I complementary deoxyribonucleic acid. Endocrinology 1990, 1 27:702-710.

II. Currie WB, Card CE, Michel FJ, Ignotz G: Purification, partial characterization, and development of a specific radioimmunoassay for goat placental lactogen. J Reprod Fertil 1990, 90:25-36.

12. Corbacho AM, Martinez de la Escalera G, Clapp C: Roles of prolactin and related members of the prolactin/growth hormonel placental lactogen family in angiogenesis. J Endocrinol 2002, 173:219-238.

13. Byatt JC, Warren WC, Eppard PJ, Staten NR, Krivi GG, Collier RJ: Ruminant placental lactogens: structure and biology. J Anim Sci 1992, 70:2911-2923.

14. Wiemers DO, Shao LJ, Ain R, Dai G, Soares MJ: The mouse prolactin gene family locus. Endocrinology 2003, I44:3 |3-325.

15. Ushizawa K, Takahashi T, Hosoe M, Kizaki K, Abe Y, Sasada H, Sato E, Hashizume K: Gene expression profiles of novel caprine placental prolactin-related proteins similar to bovine placental prolactin-related proteins. BMC Dev Biol 2007, 7:16.

16. Ushizawa K, Takahashi T, Hosoe M, Ohkoshi K, Hashizume K: Expression and characterization of novel ovine orthologs of bovine placental prolactin-related proteins. BMC Mol Biol 2007, 8:95.

17. Yamada O, Todoroki J, Kizaki K, Takahashi T, Imai K, Patel OV, Schuler LA, Hashizume K: Expression of prolactin-related pro- tein I at the fetomaternal interface during the implantation period in cows. Reproduction 2002, I 24:427-437.

18. Igwebuike UM: Trophoblast cells of ruminant placentas - A minireview. Anim Reprod Sci 2006, 93:185-198.

19. Patel OV, Yamada O, Kizaki K, Todoroki J, Takahashi T, Imai K, Schuler LA, Hashizume K: Temporospatial expression of placental lactogen and prolactin-related protein-I genes in the bovine placenta and uterus during pregnancy. Mol Reprod Dev 2004, 69:|46-I52.

20. Hashizume K, Ushizawa K, Patel OV, Kizaki K, Imai K, Yamada O, Nakano $\mathrm{H}$, Takahashi T: Gene expression and maintenance of pregnancy in bovine: roles of trophoblastic binucleate cellspecific molecules. Reprod Fertil Dev 2007, 1 9:79-90.

21. Tansey WP, Catanzaro DF: SpI and tyroid hormone receptor differentially activate expression of human growth hormone and chorionic somatomammotropin genes. J Biol Chem 1991, 266:9805-98I3.

22. Shida MM, Ng YK, Soares MJ, Linzer DI: Trophoblast-specific transcription from the mouse placental lactogen-I gene promoter. Mol Endocrinol 1993, 7:181-188.

23. $\mathrm{Ng}$ YK, George KM, Engel JD, Linzer DI: GATA factor activity is required for the trophoblast-specific transcriptional regulation of the mouse placental lactogen I gene. Development I994, I 20:3257-3266.

24. Sun $Y$, Duckworth ML: Identification of a placental-specific enhancer in the rat placental lactogen II gene that contains binding sites for members of the Ets and AP-I (activator protein I) families of transcription factors. Mol Endocrinol I999, I 3:385-399.

25. Liang R, Limesand SW, Anthony RV: Structure and transcriptional regulation of the ovine placental lactogen gene. Eur J Biochem 1999, 265:883-895.

26. Ushizawa K, Takahashi T, Hosoe M, Ishiwata H, Kaneyama K, Kizaki $\mathrm{K}$, Hashizume K: Global gene expression analysis and regulation of the principal genes expressed in bovine placenta in relation to the transcription factor AP-2 family. Reprod Biol Endocrinol 2007, 5:17.

27. Hattori N, Nishino K, Ko YG, Hattori N, Ohgane J, Tanaka S, Shiota $\mathrm{K}$ : Epigenetic control of mouse Oct-4 gene expression in embryonic stem cells and trophoblast stem cells. J Biol Chem 2004, 279: 17063-17069.

28. Nishino K, Hattori N, Tanaka S, Shiota K: DNA methylationmediated control of Sry gene expression in mouse gonadal development. I Biol Chem 2004, 279:22306-223 I3.

29. Tomikawa J, Fukatsu K, Tanaka S, Shiota K: DNA methylationdependent epigenetic regulation of dimethylarginine dimethylaminohydrolase $\mathbf{2}$ gene in trophoblast cell lineage. J Biol Chem 2006, 28I:12163-12169.

30. Hattori N, Imao Y, Nishino K, Hattori N, Ohgane J, Yagi S, Tanaka S, Shiota K: Epigenetic regulation of Nanog gene in embryonic stem and trophoblast stem cells. Genes Cells 2007, I 2:387-396.

31. Nojima H, Nagaoka K, Christenson RK, Shiota K, Imakawa K: Increase in DNA methylation downregulates conceptus interferon-tau gene expression. Mol Reprod Dev 2004, 67:396-405

32. Furuta J, Nobeyama Y, Umebayashi Y, Otsuka F, Kikuchi K, Ushijima $\mathrm{T}$ : Silencing of peroxiredoxin 2 and aberrant methylation of 33 CpG islands in putative promoter regions in human malignant melanomas. Cancer Res 2006, 66:6080-6086.

33. Yamashita S, Tsujino $\mathrm{Y}$, Moriguchi K, Tatematsu M, Ushijima $T$ : Chemical genomic screening for methylation-silenced genes in gastric cancer cell lines using 5-aza-2'-deoxycytidine treatment and oligonucleotide microarray. Cancer Sci 2006, 97:64-7I. 
34. Cho JH, Kimura H, Minami T, Ohgane J, Hattori N, Tanaka S, Shiota K: DNA methylation regulates placental lactogen I gene expression. Endocrinology 200I, I42:3389-3396.

35. Brown SE, Fraga MF, Weaver IC, Berdasco M, Szyf M: Variation in DNA methylation patterns during the cell cycle of HeLa cells. Epigenetics 2007, 2:54-65.

36. Nafee TM, Farrell WE, Carroll WD, Fryer AA, Ismail KM: Epigenetic control of fetal gene expression. BJOG 2008, I I 5: I 58- I 68.

37. Hemberger $M$ : Epigenetic landscape required for placental development. Cell Mol Life Sci 2007, 64:2422-2436.

38. Limesand SW, Anthony RV: Novel activator protein-2 $\alpha$ splicevariants function as transactivators of the ovine placental lactogen gene. Eur J Biochem 200I, 268:2390-240I.

39. Cheng $\mathrm{YH}$, Handwerger S: A placenta-specific enhancer of the human syncytin gene. Biol Reprod 2005, 73:500-509.

40. Prudhomme A, Oriol G, Mallet F: A retroviral promoter and a cellular enhancer define a bipartite element which controls env ERWEI placental expression. J Virol 2004, 78: |2 | 57- | 2 | 68.

4I. Flück CE, Miller WL: GATA-4 and GATA-6 modulate tissuespecific transcription of the human gene for $P 450 \mathrm{cl} 7$ by direct interaction with Sp I. Mol Endocrinol 2004, I 8: | | 44- | I 57.

42. Shimada A, Nakano H, Takahashi T, Imai K, Hashizume K: Isolation and characterization of a bovine blastocysts-derived trophoblastic cell line, BT-I: development of a culture system in the absence of feeder cell. Placenta 200I, 22:652-662.

43. Nakano H, Shimada A, Imai K, Takezawa T, Takahashi T, Hashizume $\mathrm{K}$ : Bovine trophoblastic cell differentiation on collagen substrata: formation of binucleate cells expressing placental lactogen. Cell Tissue Res 2002, 307:225-235.

44. Hashizume K, Shimada A, Nakano H, Takahashi T: Bovine trophoblast cell culture systems: A technique to culture bovine trophoblast cells without feeder cells. In Placenta and Trophoblast Edited by: Soares MJ, Hunt JS. New Jersey: Humana Press; 2006:179-188. [Walker JM (Series Editor): Methods in Molecular Medicine. vol I.]

45. Yamauchi N, Takazawa T, Kizaki K, Herath CB, Hashizume K: Proliferative potential of endometrial stromal cells, and endometrial and placental expression of cyclin in the bovine. J Reprod Dev 2003, 49:553-560.

46. Primer3 [http://frodo.wi.mit.edu/cgi-bin/primer3/primer3 www.cgi]

47. NCBI website [http://www.ncbi.nlm.nih.gov/mapview/map search. cgi?taxid=9913]

48. MethPrimer [http://www.urogene.org/methprimer/index.html]

49. Kanduri $C$, Raman R: Tissue-specific characterisation of DNA methylation in the gonad-specific proto-oncogene, c-mos, in the male laboratory mouse. Int J Dev Biol 1999, 43:91-94.

50. Tencomnao T, Kapitonov D, Bieberich E, Yu RK: Transcriptional regulation of the human UDP-galactose: ceramide galactosyltransferase (hCGT) gene expression: functional role of GC-box and CRE. Glycoconj ] 2004, 20:339-35I.
Publish with Bio Med Central and every scientist can read your work free of charge

"BioMed Central will be the most significant development for disseminating the results of biomedical research in our lifetime. "

Sir Paul Nurse, Cancer Research UK

Your research papers will be:

- available free of charge to the entire biomedical community

- peer reviewed and published immediately upon acceptance

- cited in PubMed and archived on PubMed Central

- yours - you keep the copyright
BioMedcentral 